\title{
O immersyjności escape roomów. Przykład pokoi Tick Tack w Gliwicach
}

Wstęp

Celem niniejszej pracy jest wykazanie, że pojęcie immersyjności stanowi dobry punkt wyjścia do analizy escape roomów (ER) oraz że to właśnie immersja odpowiada za sukces i popularność wybranych gier tego typu. Uzupełnieniem literatury źródłowej w tekście są własne doświadczenia zebrane podczas gier w lipcu 2016 roku. Przykładem udanego ER, spełniającego warunki immersyjności, są pokoje proponowane przez firmę Tick Tack z Gliwic, których konstrukcję będę analizować w tekście.

\section{Definicja i historia escape roomów}

Escape room, czyli pokój ucieczki (lub pokój zagadek) to typ gier kooperacyjnych, wymagający zazwyczaj udziału kilku graczy, którzy z własnej woli, za opłatą, pozwalają zamknąć się w specjalnie przygotowanym pomieszczeniu.

Zadaniem graczy najczęściej jest wydostanie się z zamknięcia, niekiedy dodatkowo zdobycie jakiegoś przedmiotu albo np. rozbrojenie bomby. Nicholson (2015) podejmuje refleksję nad tym, czy nazwa „pokój, z którego się ucieka” jest adekwatnym określeniem tej kategorii gier, skoro według jego badań około 30\% zbadanych przez niego pokoi ma inny cel. W niniejszym tekście skupiam się jednak przede wszystkim na ucieczce jako głównym wyzwaniu escape roomów, z tego względu, że w analizowanych przeze mnie przypadkach to właśnie taki cel został postawiony przed graczami jako nadrzędny. Należy również dodać, że prawie każda firma utrzymuje rankingi 
dotyczące jak najszybszego wydostania się z danego pokoju, wprowadzając dodatkowy element rywalizacji.

Czas przeznaczony na osiągnięcie celu jest ograniczony. Jak wynika z przeanalizowanych przeze mnie danych zebranych w portalu lockme.pl ${ }^{1}$, najczęściej jest to 60 minut, lecz zdarzają się pokoje obliczone na 45 czy 90 minut. Aby wyjść z pomieszczenia, gracze muszą rozwiązać serię różnych zagadek: logicznych, matematycznych, zręcznościowych. Każdy ER jest inny, pokoje różnią się tematyką, tłem fabularnym, zagadkami itp. Tym niemniej w wielu pokojach powtarzają się zarówno motywy przewodnie, jak i typy stosowanych zagadek.

Nie istnieje jedna naukowa definicja ER. Spośród różnych możliwości w niniejszym tekście będę odwoływać się do prac Nicholsona - współczesnego badacza, a równocześnie projektanta ER. Definiuje on ER jako „rozgrywane na żywo gry zespołowe, w których gracze odkrywają wskazówki, rozwiązują zagadki, wykonują zadania $\mathrm{w}$ jednym lub więcej pomieszczeniach w celu osiągnięcia konkretnego celu (zazwyczaj ucieczki z pomieszczenia) w ściśle ograniczonym czasie"2 (Nicholson, 2015, s. 1). Uważam, iż jest to definicja satysfakcjonująca, zawierająca kluczowe dla ER elementy w charakterystycznej konfiguracji. Dodałabym jedynie, że wszystkie wymienione działania są osadzone w określonej historii, z którą związany jest wystrój pokoju i zamieszczone w nim wyzwania dla graczy.

Przez wiele lat gry mające część wskazanych cech były tylko i wyłącznie cyfrową formą rozrywki. Jako pierwowzór obecnych ER często wskazuje się komputerowe gry przygodowe typu „point and click”, w których gracz musiał rozwiązywać zadania i prowadzić swojego bohatera za pomocą wskaźnika myszy (Kowalik, 2015; Podgórski, 2016). Dziennikarka Anna Kowalik uważa, że wpływ na rozwój ER miały także programy rozrywkowe typu Fort Boyard albo The Crystal Maze (Kowalik, 2015). Jest to dobry trop, o czym świadczyć może Activity Escape Room (Activity Escape, 2017), jeden z katowickich ER, którego twórcy wprost wskazują Fort Boyard jako inspirację dla ich gry. Złożoną genezę ER przedstawia Nicholson, wskazując aż sześć zjawisk prekursorskich dla tej formy. Oprócz wymienionych już komputerowych gier przygodowych (point-and-click adventures) i telewizyjnych widowisk (adventure game show \& movies) wymienia także gry typu LARP (live-action role playing), poszukiwanie

1 Strona lockme.pl to spis wszystkich dostępnych w Polsce ER. Przy opisie każdego pokoju znajduja się podstawowe informacje o nim, takie jak czas trwania gry, poziom trudności, dopuszczalna liczba graczy. Strona oferuje również możliwość wystawiania recenzji po odwiedzeniu danego pokoju; dla wielu graczy jest to pierwsze miejsce wymiany informacji i opinii.

2 Cytaty z tekstów anglojęzycznych zostały podane w przekładzie własnym. 
skarbów (puzzle \& treasure hunts), interaktywny teatr i domy strachu (interactive theater \& haunted house) oraz tematyczny przemysł rozrywkowy (themed entertainment industry). (Nicholson, 2015, s. 3-6).

W 2006 roku w Dolinie Krzemowej w USA odbyła się gra Real Life Escape Room. Stworzyła ją grupa programistów, a scenariusz zabawy oparto na powieściach kryminalnych Agathy Christie. Choć nie był to escape room w dzisiejszym rozumieniu, właśnie to wydarzenie jest wskazywane przez polskich badaczy (Kowalik, 2015; Podgórski, Stasiak, 2016) jako początek historii dzisiejszych ER ${ }^{3}$. Do Europy ER dotarły w 2010 roku, a w Polsce pierwszy pokój otworzono w 2013 roku we Wrocławiu (Kowalik, 2015; Podgórski, 2016). Jest to coraz bardziej popularna rozrywka, o czym świadczy fakt, że na całym świecie wciąż przybywa nowych pokoi. Powstają strony internetowe dotyczące tej rozrywki, tworzą się związane z nimi społeczności, a ER stały się jedną z atrakcji turystycznych, o których piszą portale związane z podróżami, np. tripadvisor.com. Również w literaturze naukowej można wskazać już prace, które analizują rynek ER nie z punktu widzenia game studies, a właśnie z perspektywy turystyki (Kubal, Pawlusiński, 2016; Stasiak, 2016). W rozmowach z pracownikami pokoi przeprowadzanych przeze mnie w latach 2016-2017 powtarzała się opinia, że ta forma rozrywki zyskuje uznanie również wśród osób niemających wcześniejszych doświadczeń z grami. Rozmówcy wskazywali m.in. na rosnącą popularność voucherów do ER. Prawdopodobnie więc ER trafiają nie tylko do zadeklarowanych graczy, ale też do znaczącej liczby osób niezwiązanych z żadnym typem gier. Z czego wynika ich tak duża popularność, nie tylko wśród zadeklarowanych graczy, ale także w środowiskach niezwiązanych z jakimikolwiek grami?

\section{Escape room a immersja}

Wydaje mi się, że odpowiedź na zadane przeze mnie pytanie tkwi w modnym ostatnio słowie, jakim jest „immersja”. To termin stosowany przez ludologów głównie w odniesieniu do gier komputerowych, ale wiele uwagi poświęca mu się także w kontekście LARP-ów $^{4}$ (Koljonen, 2015; Wicher, 2016; Pilc, 2017). Przez rożnych badaczy immersyjność jest różnie definiowana. Definicje te obejmują zaangażowanie, specyficzny sposób postrzegania rzeczywistości, uzależnienie, „zawieszenie niewiary” czy iden-

3 Warto jednak zauważyć, że dla Nicholsona historia ER rozpoczyna się dopiero w 2007 roku w Japonii, kiedy Katao Tako otworzył pierwszy REG (Real Escape Game). (Nicholson, 2015, s. 3).

4 LARP (ang. live action role-playing) to rodzaj aktywności na pograniczu gry i sztuki, podczas której gracze wcielają się w role, przy zachowaniu założenia tożsamości ciała gracza i postaci, oraz wspólnie tworzą i przeżywają opowieść. 
tyfikację z bohaterami (Calleja, 2011). W niniejszej pracy rozumiem immersyjność jako bardzo silne zaangażowanie w gre, wynikajace $z$ dobrze zaprojektowanej historii. Zakładam też, że w przypadku ER osiągnięcie immersji jest łatwiejsze niż w grach komputerowych z uwagi na niezapośredniczony charakter rozrywki.

Laura Ermi i Frans Mäyrä (2005) wyróżnili trzy typy immersji: sensoryczną, opartą na wyzwaniu i wyobrażeniową. Podział taki jest bardzo przydatny w przypadku ER, ponieważ zwraca uwagę na rożne aspekty tego rodzaju gier, często też te, które pomijają sami projektanci.

Immersja oparta na wyzwaniu w mniejszym lub większym stopniu realizowana jest niemal przez każdy ER, ponieważ - jak opisano wcześniej - wyzwanie „wydostań się z pokoju” jest nadrzędnym celem każdego z interesujących mnie ER. Gracze podejmują wyzwanie, chcą się sprawdzić i wyjść w jak najkrótszym czasie. Właśnie po to poświęcają swój czas i pieniądze: aby podołać postawionym przed nimi zadaniom. Jednym warunkiem osiągnięcia przez graczy tego rodzaju immersji jest odpowiednie określenie poziomu trudności przez twórców. Jego zawyżenie może sfrustrować mniej doświadczonych graczy, zaniżenie natomiast - rozczarować graczy zaawansowanych.

\section{Escape room Tick-Tack w Gliwicach Immersja w Tick-Tack}

Dwa pozostałe typy immersji zdefiniowane przez Ermi i Mäyrä są dużo trudniejsze do osiągnięcia. Zostaną omówione na przykładzie pokoi firmy Tick Tack w Gliwicach, Egiptu i Tortugi. Wybór ten był nieprzypadkowy: pokój Tortuga podczas moich odwiedzin (w sierpniu 2016 roku) znajdował się na pierwszym miejscu w rankingu wszystkich ER w Polsce według portalu lockme.pl ${ }^{5}$. Ponadto jest to jedyna z 24 odwiedzonych przeze mnie osobiście firm, w której zetknęłam się z tak kompleksowym podejściem, obejmującym wszystkie trzy aspekty immersyjności gry.

Osiągnięcie immersji sensorycznej zależy przede wszystkim od jakości i sposobu wykonania danego pokoju oraz od sprostania wyobrażeniom gracza o proponowanym temacie rozgrywki. Gracz znajduje się w jakiejś przestrzeni, ale to, czy uwierzy w jej prawdziwość, w znacznej mierze zależy od pracy włożonej przez twórców pokoju. Zwraca na to uwagę Nicholson:

5 Z kolei w marcu 2018 roku znajdował się na czwartym miejscu, a w listopadzie 2018 roku - na miejscu osiemnastym. 
Ponieważ [w ER] gracz nie siedzi, oglądając [tylko] awatara w świecie gry, jest bardziej czuły na te elementy w grze, które nie są zgodne z danym gatunkiem, scenografią czy narracją. Gracze, którzy poszukują immersyjnych wrażeń, mogą być sfrustrowani w obliczu dostrzeżonego dysonansu poznawczego pomiędzy tym, kim mają być w grze, i tym, co w niej robią. (Nicholson, 2016, s. 1).

Nicholson stworzył dla twórców ER prostą strategię „Ask why”. Proponuje ona, aby wobec każdego elementu danego pokoju zadać pytanie: „Dlaczego to tutaj jest?”. Każdy element powinien mieć logiczny narracyjny powód, dla którego tam się znajduje. Ponadto wszystkie wyzwania stawiane przed graczami powinny mieć wyjaśnienie i uzasadnienie w wykreowanym świecie (Nicholson, 2016). Twórcy Tick Tacka spełniają kryteria stworzone przez Nicholsona: zarówno w pokoju Egipt, jak i w Tortudze nie znajdziemy elementów zbędnych lub niepasujących do tematu.

\section{Pokój Egipt}

Gra w Egipcie rozpoczyna się na małej przestrzeni, pełnej piasku, tuż przy wejściu do piramidy, którą stanowi fragment muru wybudowany z prawdziwego piaskowca. Wykorzystane materiały, tj. prawdziwy piasek oraz naturalny kamień, a także rzeczywista konstrukcja muru, bardzo urealniają grę. Pierwszym zadaniem graczy jest znalezienie sposobu na wejście do środka piramidy, a kolejnym, kluczowym wyzwaniem - zapalenie światła (wnętrze piramidy pogrążone jest w ciemnościach). Aby tego dokonać, należy umieścić znalezioną uprzednio pochodnię w odpowiednim miejscu.

Zwracam uwagę na logikę zagadek i ich zgodność z tłem fabularnym. Światło nie zapala się po wciśnięciu odpowiedniego guzika na ścianie czy wpisaniu kodu, tylko poprzez „zapalenie” pochodni. Zagadki bazują wyłącznie na wiedzy, kulturze, religii i technice dostępnej w starożytnym Egipcie. W całym pokoju nie ma ani jednej kłódki, co twórcy w rozmowie ze mną wytłumaczyli bez zastanowienia: „ponieważ wtedy nie było kłódek”. W pokoju wszystko jest na swoim miejscu, nie ma niczego niepotrzebnego, niczego niepasującego do wystroju. Mamy więc grobowiec z mumią w środku, egipskie hieroglify do rozszyfrowania, zagadkę logiczną dotyczącą hierarchii społecznej ówczesnego Egiptu i posążki egipskich bóstw, a więc wszystkie elementy, które są pierwszymi skojarzeniami związanymi ze starożytnym Egiptem i odpowiadają wyobrażeniom graczy o nim. 
Pokój Tortuga

W drugim pokoju, tj. Tortudze, gdzie akcja toczy się na pokładzie statku, twórcy przygotowali wiele niespodzianek w postaci ukrytych korytarzy i podpokładów. Całe wnętrze wykonane jest $\mathrm{z}$ naturalnego drewna. Podobnie jak w poprzednim pokoju, tutaj zagadki również są tematyczne, tj. związane ze społecznością piracką oraz żeglowaniem. Musimy więc czytać mapy, rozpoznawać kierunki świata, zbierać takie pirackie akcesoria jak szable i bandery, otwierać tajemnicze pudełka i skrzyneczki, a ponadto obsługiwać żagle - w pomieszczeniu znajduje się bowiem maszt i dwa prawdziwe żagle oraz koło sterowe. Zarówno wszystkie elementy wystroju, jak i przygotowane zagadki oddają doświadczenie bycia na statku i jego przeszukiwania.

\section{Sposób prowadzenia narracji}

Wykonanie pokoju jest bardzo istotnym elementem każdego ER. Choć jest to najdroższy element przygotowania pokoju, przy bardzo dużej konkurencji na rynku twórcy zwracają na niego coraz większą uwagę. Można to zauważyć, regularnie odwiedzając escape roomy - im nowszy pokój, tym wyższy poziom i staranność wykonania. Tym bardziej dziwi fakt, że odpowiedzialny za osiągnięcie immersji wyobrażeniowej narracyjny element gry, który wymaga najmniejszych nakładów finansowych, jest najczęściej zaniedbywanym aspektem tej rozrywki.

Na narracyjny aspekt ER wielką uwagę zwraca Nicholson. W swoim artykule, w całości poświęconym właśnie temu zagadnieniu, zauważa, że tylko połowa z przebadanych przez niego pokoi jest logicznie spójna. Wskazuje również wiele przykładów anachronizmów, niespójności czy braków konsekwencji, w postaci np. laserów w pokoju dotyczącym starożytnego Egiptu (Nicholson, 2016). Taka sprzeczność między opowiadaną przez twórców historią a rozwiązaniami, z którymi mamy do czynienia w mechanice gry, nazywana jest przez badaczy gier dysonansem ludonarracyjnym (Hocking, 2007).

Cała działalność firmy Tick Tack wyróżnia się przede wszystkim właśnie narracyjną spójnością. W czasie pisania artykułu firma obsługiwała dwa pokoje i pracowała nad trzecim, którego otwarcie planowano na lipiec 2018 roku. Wyjątkową cechą było tutaj zachowanie ciągłości fabularnej nie tylko w obrębie każdego z pojedynczych pokoi, lecz także pomiędzy dwoma zupełnie innymi pokojami. Z rozmowy z właścicielami dowiedziałam się, że trzeci pokój również wpisze się w tę ciągłość. Pomysł Tick Tacka polega na tym, że właściciele - pełniący jednocześnie funkcję narratorów opowieści - wprowadzają uczestników gry w fabułę, przyjmując rolę naukowców, którym udało się skonstruować pierwsze na świecie wrota czasu. Jest to niezwykle 
znamienne, ponieważ to jedyna odwiedzona przeze mnie dotąd firma, w której wykorzystano element live-action role playing. O ile proponowanie fabularnej roli graczom jest dosyć powszechnym zabiegiem, o tyle z przyjęciem określonej roli przez mistrzów gry jeszcze się w innym miejscu nie zetknęłam. Zapewne silny wpływ na to miały wcześniejsze intensywne doświadczenia twórców pokoju właśnie z LARP-ami, o których wspominali w przeprowadzonej rozmowie.

Pierwsze przejście prowadzi do starożytnego Egiptu, drugie - na statek piracki krążący po karaibskich morzach w latach świetności piratów. Fabularnym zadaniem graczy, zarówno w pierwszym, jak i drugim wypadku, jest uratowanie członków wcześniejszych ekspedycji wysłanych przez wrota czasu.

\section{Emersja w Tick-Tack}

Dodatkowym czynnikiem w ER jest limit czasu gry, który pełni kluczową funkcję, wymuszając koncentrację, współpracę i zaangażowanie. Nie ma możliwości zapisania stanu gry i zrobienia przerwy, a każda minuta jest bezcenna - straconego czasu nie da się odzyskać ani nadrobić. W związku z tym ogólnie przyjętą zasadą gier tego typu jest możliwość uzyskania wskazówek od organizatorów. W zależności od wcześniejszych ustaleń prowadzący podają sugestie z własnej inicjatywy lub tylko na życzenie graczy. Podpowiedzi są przekazywane albo ustnie poprzez głośnik bądź walkie-talkie, albo w formie pisanej na ekranie monitora lub tabletu znajdującego się w pokoju.

System podpowiedzi jest najbardziej emersyjnym elementem ER. Emersja to termin stworzony przez Piotra Kubińskiego (2014) jako przeciwieństwo immersji. Autor określa tym mianem takie elementy gry komputerowej, które przypominają, że to tylko gra. Kubiński zwraca uwagę na fakt, że czynniki emersyjne nie mają wyłącznie charakteru incydentalnego; mogą też być zaplanowanym narzędziem twórców. Uważam jednak, że w przypadku Escape roomów wynika ona wyłącznie z konieczności i braku pomysłowych rozwiązań.

Tick Tack bardzo sprytnie rozwiązał problem emersyjności podpowiedzi, wpisując je w warstwę diegetyczną gry. Bardzo dobrze odpowiada to strategii diegetyzacji interfejsu opisanej w kontekście gier komputerowych przez Kubińskiego (2016). Zarówno w Egipcie, jak i w Tortudze podpowiedzi przekazywane są graczom za pomocą walkie-talkie. Od początku bowiem wiadomo, że uczestnicy gry mają kontakt z bazą, a mistrzowie gry to twórcy wrót, którzy dysponują informacjami przekazanymi przez poprzednie ekipy przed zaginięciem. W związku z tym mogą służyć do pewnego stopnia radą i pomocą. Dotychczas nie spotkałam się z innym pokojem, w którym tak wielką uwage projektanci przywiązywaliby do fabularnego wprowadzenia i spójności narracji. 


\section{Przestrzeń w Tick-Tack}

Dla właścicieli istotne było nie tylko wykonanie pokoi, ale też urządzenie całej przestrzeni firmy. Zdarza się to bardzo rzadko, gdyż ograniczenie przestrzeni niezwiązanej z samą grą pozwala w prosty sposób redukować koszty prowadzenia biznesu. W Tick Tack na początku wkraczamy do gabinetu naukowców i podróżników w czasie. Na ścianach wiszą mapy, w salonie uwagę przyciąga przede wszystkim duży globus. Pierwsze skonstruowane wrota czasu, prowadzące do starożytnego Egiptu, znajdują się po lewej stronie, bezpośrednio przy głównym gabinecie. Cała przestrzeń związana jest z grą, a koncepcja „Ask Why” Nicholsona (2016) realizuje się zarówno w samych pokojach, jak i w całym lokalu. Właściciele od progu grają swoją rolę, witają nas w swoim gabinecie i przedstawiają wyzwanie. Płynnie wkraczamy do świata gry ze świata zewnętrznego, a granica między nimi zostaje zatarta.

Zaprojektowanie ER zgodnie z wytycznymi opracowanymi przez Nicholsona jest ważne $\mathrm{z}$ jeszcze jednego powodu. Ich niespełnienie może bowiem skutkować brakiem zaangażowania ze strony graczy, a co gorsza - ich frustracją. Jak zauważa autor, gracze wybierają pokój ze względu na to, co chcą robić podczas rozgrywki, kierując się proponowanym przez twórców gatunkiem i konwencją pokoju (np. horror, science-fiction, kryminał). Zaburzenie konwencji lub niedostosowanie rozgrywki do proponowanego tematu może doprowadzić do nieprzyjemnego rozdźwięku między tym, czego gracze oczekiwali, a tym, co otrzymali (Nicholson, 2016).

Dla zaistnienia immersyjności ważna jest także procedura samego wprowadzenia graczy do pokoju. Najczęściej mistrz gry opowiada krótką historię, otwiera drzwi i wprowadza graczy do pomieszczenia. W takim wypadku zaangażowanie w grę może się rozpocząć dopiero w samym pokoju. W Tick Tacku natomiast zadbano o uatrakcyjnienie momentu wprowadzającego. Gracze dostają specjalne okulary z zaciemnionymi szybami, które mają im uniemożliwić przedwczesne zobaczenie niektórych elementów pokoju, jednak twórcy gry również ten szczegół uzasadniają fabularnie, jako ochronę przed intensywnym światłem pojawiającym się w trakcie podróży w czasie. Rzekomo są to też okulary przekazujące obraz do bazy; twórcy zabawy często o tym przypominają, prosząc o ich założenie, gdyż „nie mają obrazu i nie mogą pomóc”. Wejście do pokoju odbywa się w ciemności, przy równoczesnym wsłuchiwaniu się w maszynowe odgłosy, które to zabiegi pomagają graczom uwierzyć, że rzeczywiście podróżują w czasie i przestrzeni. 


\section{Podsumowanie}

Na podstawie odwiedzin w licznych escape roomach, rozmów z ich właścicielami, obsługą oraz odwiedzającymi je graczami - i na przykładzie pokojów gliwickiej firmy Tick-Tack - mogę sformułować następujące wnioski dotyczące immersyjności escape roomów.

Po pierwsze, dobrze zaprojektowany ER pozwala graczom na osiągnięcie stanu immersji, dzięki czemu uczestnicy uzyskują możliwość doświadczenia czegoś nowego. W swoim artykule Nicholson przywołuje krótkie stwierdzenie Lee Sheldona dotyczące tego, czego uczestnicy kultury chcą od opowieści: „Zabierz mnie do miejsca, w którym nigdy nie byłem. Uczyń mnie kimś, kim nigdy nie będę. Pozwól mi robić rzeczy, których nigdy nie zrobię" (Sheldon, 2014, za: Nicholson, 2016). Myślę, że każdy ER, który dostarczy tych trzech rzeczy, staje się immersyjny i pozostawia graczom niezapomniane przeżycia.

Po drugie, każdy ER proponuje grę w czasie rzeczywistym i w określonym miejscu, to jednak jeszcze nie gwarantuje immersji. W Tick Tacku dodano do tego spójną wizję pokoi, spełniającą założenia strategii Nicholsona „Ask Why”, a równocześnie realizującą wszystkie trzy typy immersji zdefiniowane przez Ermi i Mäyrä. Dzięki temu gracze mogą zostać całkowicie wciągnięci w opowieść. Mogą zapomnieć, że to gra.

Po trzecie, nowo budowane i otwierane escape roomy są coraz bardziej skupione na zapewnieniu immersyjności gry, tym samym zbliżając się gatunkowo do LARP-ów. Wobec rosnących wymagań graczy firmy i pokoje niezapewniające wysokiego poziomu immersji zamykają się i znikają ze stale rosnącego rynku polskich escape roomów.

\section{Bibliografia}

Activity Escape (2017). O grze. Online: http://activityescape.pl/ [data dostępu: 2 stycznia 2017].

Calleja, G. (2011). In-game from immersion to incorporation. Cambridge, Mass: MIT Press.

Ermi, L., Mäyrä, F. (2005). Fundamental Components of the Gameplay Experience: Analysing Immersion.

Escape City. (b. d.) About our games. Online: https://www.escapecity.ca/about-ourgames [data dostępu: 2 stycznia 2017]. 
Hocking, C. (2007). Ludonarrative Dissonance in Bioshock. Online: http://clicknothing.typepad.com/click_nothing/2007/10/ludonarrative-d.html [data dostępu: 2 stycznia 2017].

Koljonen, J. (2015). Eye-Witness to the Illusion. On the Impossibility of $360^{\circ}$ Role-Playing. W: A. Fedoseev, J.T. Harviainen, O. Vorobyeva (red.) Nordic-Russian Larp Dialog (s. 103-113). Moskwa: Comcon.

Kowalik, A. (2015). Ucieczka od pieniędzy. Online: http://pierwszymilion.forbes.pl/ escape-roomy-podbijaja-polske,artykuly,191344,1,1.html\# [data dostępu: 2 stycznia 2017].

Kubal, K., Pawlusiński, R. (2016). Escape Rooms - nowe zjawisko w przestrzeni turystycznej Krakowa. Annales Universitatis Paedagogicae Cracoviensis. Studia Geographica, 7(2): 244-258.

Kubiński, P. (2014). Emersja - antyiluzyjny wymiar gier wideo. Nowe Media, 5(1): 161-176.

Kubiński, P. (2016). Emersja: strategie estetyczne interfejsów użytkownika w grach wideo. Techsty, 1(10).

Lock Me. (b.d.) Co to jest escape room, na czym polega? Online: www.lockme.pl [data dostępu: 2 stycznia 2017].

Nicholson, S. (2015). Peeking behind the locked door: A survey of escape room facilities. Online: http://scottnicholson.com/pubs/erfacwhite.pdf [data dostępu: 2 stycznia 2017].

Nicholson, S. (2016). Ask why: creating a better player experience through environmental storytelling and consistency in escape room design. Online: http://scottnicholson.com/pubs/askwhy.pdf [data dostępu: 2 stycznia 2017].

Pilc, A. (2017). Immersja w 4 prostych krokach, czyli jak wykreować postać, która na dlugo zapadnie w pamięć. Online: http://kola.org.pl/wp-content/uploads/2017/04/ Kola\%C5\%BC.-O-larpach-inaczej-publikacja-Kola-2017.pdf, s. 9-10 [data dostępu: 31 marca 2018].

Podgórski, D., (2016). Escape Room - dlaczego świat oszalał na punkcie ucieczki z pokoju? Online: http://gry.onet.pl/artykuly/escape-room-dlaczego-swiat-oszalal-napunkcie-ucieczki-z-pokoju/8pbp77 [data dostępu: 2 stycznia 2017].

Sheldon, L. (2014). Character development and storytelling for games (2nd edition). Boston: Course Technology PTR.

Stasiak, A., (2016). Escape Rooms - nowa oferta sektora rekreacji w Polsce. Turyzm, 26(1) [data dostępu: 21 lutego 2018].

Wicher, M. (2014). Czego nauczyly mnie larpy symulacyjne. Online: http://kola.org.pl/ wp-content/uploads/2016/11/publikacja-Kola-2014.pdf, s. 26-27. [data dostępu: 31 marca 2018]. 


\section{Abstrakt}

Escape room (ER) to rodzaj kooperacyjnej gry rozgrywanej na żywo. Polega na znalezieniu w określonym czasie wyjścia z zamkniętego pomieszczenia lub wykonaniu innego, dodatkowego celu misji poprzez rozwiązanie serii zagadek i łamigłówek. Dotychczas niewiele prac zostało poświęconych ER, szczególnie w środowisku polskich badaczy gier. Niniejszy artykuł jest próbą wypełnienia tej luki. W tekście przedstawiono krótką historię powstania ER oraz postawiono tezę, że przyczyną sukcesu i popularności wybranych ER jest immersyjność. Zagadnienie immersyjności ER oraz warunki, jakie powinien spełnić dany pokój, aby w pełni zaangażować graczy, omówiono na przykładzie pokoi firmy Tick Tack z Gliwic. Analizę przeprowadzono na podstawie literatury źródłowej oraz własnych doświadczeń z gry.

Słowa kluczowe: escape room, immersja, emersja, dysonans ludonarracyjny

\section{Abstract}

Escape room (ER) is a live cooperative game in which players need to find a way out of a closed room, or to reach an additional goal by solving a series of riddles and puzzles, in a set amount of time. So far there have been few publications on ERs, particularly in Polish game studies. This paper is an attempt at filling this gap. The history of ERs is described briefly, and the claim is made that the reason for the success and popularity of selected ERs is their immersivity. The rooms of the company Tick Tack, which is located in Gliwice, are used as examples to discuss the topic of ER immersivity and the conditions that a room should meet to engage players fully. The analysis is based on relevant literature and on the author's own experiences with ERs.

Keywords: escape room, immersion, emersion, ludonarrative dissonance 
Autorka

Katarzyna Julke-Bogacka (kasia.julka@gmail.com) - absolwentka Kulturoznawstwa na Uniwersytecie Opolskim, obecnie studiuje Sztuki Wyzwolone na Wydziale Artes Liberales Uniwersytetu Warszawskiego. W polu jej zainteresowań znajduje się szeroko rozumiana kultura popularna, ze szczególnym uwzględnieniem różnego rodzaju gier: planszowych, RPG, komputerowych czy escape roomów. Związana z Naukowym Kołem Badania Gier ALEA UW. 